International Journal of Multidisciplinary Research AND ANALysis

ISSN(print): 2643-9840, ISSN(online): 2643-9875

Volume 05 Issue 01 January 2022

DOI: 10.47191/ijmra/v5-i1-27, Impact Factor: 6.072

Page No.- 220-224

\title{
Coverage of Problems in the Ethnic History of the Population of Kashkadarya and Surkhandarya Oases in the Scientific Researches during the Years of Independence
}

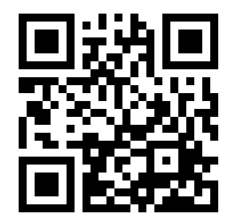

\author{
Alisher Nasimov \\ Researcher, Karshi State University Karshi, Uzbekistan
}

ABSTRACT: The article presents some studies reflecting the historiography of the ethnology of the southern regions in the first years of independence, including K.Sh. Shaniyozova, A.A. Askarova, B.A. Akhmedova, I. Jabborova, A.A. Ashirova, O.Burieva, F. Ochildieva and others. Kayumov, N. Tursunov, R. Radzhabov, M. Usmanov, O. Dzhurakulov, P. Ravshanov, local historian B. Pulatova and others.

To date, no special scientific works on the historiography of ethnology of the southern regions of Uzbekistan have been carried out and scientific literature on this topic has not been published. Basically, the study provides information about the main components that are actively involved in the formation of the Uzbek people. In addition, attempts have been made to show that the southern regions of Uzbekistan have been home to settlers since ancient times and that Uzbek tribes mingled with settlers who have lived in these regions since ancient times and are the heirs of their material and material values. spiritual culture.

KEYWORDS: ethnography, historiography, southern regions of Uzbekistan, Uzbeks, the process of self-awareness, independence.

\section{INTRODUCTION}

The study of the history of the people of Central Asia, the collection of information about their past, in particular, their ethnology, has also been of interest and importance to researchers living in ancient times. Preliminary data on the history and ethnography of the ancestors of the Uzbek people also date back to ancient times. Especially after the formation of the Uzbek people as a single nation, we are witnessing the enrichment and increase of such information.

Due to the fact that our history was previously written under the influence of the dominant idea, a one-sided approach to the events that took place, many events and incidents were covered from a class point of view, and events related to the history of the Soviet period were distorted. In particular, all the achievements were said to be the product of a socialist system, sometimes exaggerated, and its negative consequences were partially reflected in Soviet-era research. Therefore, it is necessary to reconsider this page of our history conceptually and methodologically, to study it more deeply on the basis of sources. It is necessary to study and analyze various historical sources, critically evaluate, correctly interpret and reveal the true and complete picture of our history.

After the independence of Uzbekistan, historians were tasked to reveal the areas that were distorted or poorly studied during the Soviet era, and in the past, some progress has been made in this area. In the twentieth century, many different volumes of research on the ethnography of different ethnic groups and populations in the southern regions of Uzbekistan were published. Generalization, systematization, analysis of different approaches from the point of view of historiography is a topical issues in today's historiography, and this urgency requires special research in this area.

\section{METHODS AND LEVEL OF STUDY}

Analysis of relevant sources and literature shows that the first steps are being taken in Uzbekistan in the field of ethnological (ethnographic) historiography. It was noted that more effective research is needed in this area, and there are still many unresolved issues in this area. In particular, no special scientific work on the historiography of ethnology of the southern regions of Uzbekistan has been conducted or scientific literature on this topic has not been published.

Historiographical works devoted to the analysis of ethnographic research carried out before the independence of our country were one-sided, did not show the scientific-practical value and scientific significance of the studied problems, and often 


\section{Coverage of Problems in the Ethnic History of the Population of Kashkadarya and Surkhandarya Oases in the Scientific Researches during the Years of Independence}

had a bibliographic description. However, it is impossible not to mention the path of ethnography in Uzbekistan and the scientific value of this work in the study of ethnology of the Uzbek people.

In the first years of independence, some works reflecting the historiography of the ethnology of the southern regions were created. In particular, information on the state of study of certain issues related to the historiography of ethnography of the Kashkadarya and Surkhandarya oases is given in In the scientific works of K.Sh. Shoniyozov, A.A. Asqarov, B.A. Ahmedov, I. Jabborov, A.A. Ashirov, O. Buriev, F. Ochildiev and A.R. Kayumov, as well as in the multi-volume book "Uzbeki" under the heading "Narody i kultury"

From the last quarter of the twentieth century, a new era began in the study of the ethnography of the southern oases. The dissertation is defended by a group of scientists working in the oases. In particular, O. Buriev, S. Davlatova, O. Ibragimov, M. Ibragimova, K. Kubakov, K. Nasriddinov, F. Rakhmonov, G. Tosheva, N. Tursunov, B. Khamrokulova, P. Norbutaev in the introductory part of the candidacy Kashkadarya and the study of the ethnic history, material and spiritual culture, customs and traditions of the population of the Surkhandarya region.

\section{RESEARCH RESULTS}

One of the most important problems in ethnology during the years of independence is, of course, the study of the ethnogenesis and ethnic history of the Uzbek people. The researches of the well-known scientists of the republic K. Shoniyozov [1], A.A. Askarov [2], B.A. Akhmedov [3] and I. Jabbarov [4] in this direction are of special interest. These studies provide information on the ethnic history and ethnic composition of the population of the southern regions of Uzbekistan.

For the first time, K. Shoniyozov developed a theoretical and methodological concept of the formation of the Uzbek people, based on the historical foundations of ethnic processes in Central Asia. He elaborated his new scientific conclusions on complex ethnic processes in such articles as "Some theoretical issues of ethnogenesis of the Uzbek people" and "Some issues of the process of formation of the Uzbek people" [5].

Relying on a large number of historical, anthropological, archaeological, numismatic and ethnographic sources of the 1990s, K. Shoniyozov's views on ethnic components that played an important role in the ethnogenesis and ethnic history of the Uzbek people are a direct source of coverage of the ethnic history of the region.

K. Shoniyazov's views on the formation of the Uzbek people are valuable as an important theoretical and methodological basis in the study of the formation and ethnic history of the population of the southern oases. The scientist notes that the Uzbek people, unlike other Turkic-speaking people in the region, was formed in the process of mixing of peoples of the two languages (Turkish and Iranian).

K. Shoniyazov conducts fundamental research, systematizing his many years of research on the ethnogenesis and ethnic history of the Uzbek people. His work "The process of formation of the Uzbek people" [6] is one of the fundamental researches in Uzbek ethnology. This monograph is an important guide that fills a certain gap in the coverage of the problems of ethnogenesis and ethnic history. In our opinion, this work is the first in history to cover many aspects of the subject, and the author states new scientific views on the ethnogenesis and ethnic history of the Uzbeks, a number of theoretical issues. In general, the author has been able to shed light on the problem of ethnogenesis and ethnic processes, as well as the process of formation of the Uzbek people, which has not yet been sufficiently developed. K. Shoniyazov also notes that during the study, some issues related to the history of the ethnos have not yet been resolved. Based on the scientific conclusions of the author's monograph, it is possible to obtain valuable information on the problems of population formation and ethnic history of the southern regions of Uzbekistan.

The views expressed in the works of Academician A.A. Askarov on the theoretical and methodological problems of ethnic history and ethnogenesis of the Uzbek people serve as a theoretical and methodological basis for covering the formation of the population of the southern oases and ethnic history [7]. K. Shoniyazov, A. Doniyorov and A. Ashirov commented on the scientific and practical significance of these articles in their work [8].

In 2015, a new, fundamental work by A. Askarov was published [9]. In this monographic study about the origin of the Uzbek people, that is, its long ethnogenesis and ethnic history, the process of its gradual formation into a tribal state and stages of reaching the level of a nation as a formed nation are described on the basis of a scientific analysis of the rich material culture and written sources.

The works of historian B. Ahmedov, published during the years of independence, also serve as an important source for researchers studying the ethnic history of the Uzbek people [10]. His book, Lessons from History, covers the medieval history of Uzbeks. The value of the book for our topic is that it provides an opinion on the manuscript sources on the ethnic history of the Uzbek people and their content. 


\section{Coverage of Problems in the Ethnic History of the Population of Kashkadarya and Surkhandarya Oases in the Scientific Researches during the Years of Independence}

A number of works by I. Jabborov on the ethnology of the peoples of the world and the Uzbek people also address the problem of ethnic processes in Central Asia [11]. In the first years of independence, the scientist published a work on the ethnography of the Uzbek people. This book reflects the origins and ethnic history of the Uzbek people, their location. The information provided in it is a direct reference to the ethnic processes that took place in the Kashkadarya and Surkhandarya oases and the ethnic composition and location of the population.

Another work by I. Jabborov is called "Uzbeks: lifestyle and culture". This book is a revised and supplemented copy of the book of the scientist "Ethnography of the Uzbek people", which enriches the current ethnic and ethnocultural processes with new information. The author's information on the ethnic persecution and location of the Uzbek people helps to shed light on ethnic processes in the southern regions. The author notes that on the eve of the twentieth century, the Uzbek people consisted of three major ethnic groups (subethnos).

During the years of independence, the issues of ethnic processes in the southern oases of Uzbekistan and the ethnic composition and location of the population were reflected in the work of O. Buriev. O. Buriev's research is important because it is in them the only historical and ethnographic region in terms of territories, geographical location, nature, economy, origin (ethnogenesis) of the population and the eternal harmony of their historical destinies, in short, the commonality of material and spiritual cultures and ethnography of Kashkadarya and Surkhandarya regions, which are historical and ethnographic regions are always illuminated on the basis of a comparative analysis with each other.

Many of O. Buriev's works are directly devoted to the ethnic composition, ethnic history and location of the population of the southern regions. Among them, the ethnological dictionary co-authored by T. Khojamberdiev and his joint work with M. Usmanov [12] summarized this issue and achieved positive results in its study. In the book "Brief glossary of ethnological terms" the authors describe the ethnic history, number, location, ethnonym and ethnotoponym of Uzbek tribes and other nations living in the south of Uzbekistan on the basis of a large number of historical and ethnographic sources.

O. Buriev and M. Usmanov also work on the ethnic history and ethnocultural processes of Uzbeks, the most important sources on the ethnogenesis and ethnic history of the Uzbek people and a brief commentary on the ethnic history of the Uzbek people. The play also tries to cover the ethnocultural processes that took place in the past in some large regions of Uzbekistan (Samarkand, Kashkadarya and Surkhandarya oases) and the ethnic history of large Uzbek people on the basis of many historical and ethnographic sources.

In recent years in the researches of historians and ethnologists A. Kayumov, N. Tursunov, R. Rajabov, M. Usmanov and historian F. Ochildiev Ethnic processes in the Kashkadarya and Surkhandarya oases, the problems of ethnic history and ethnic composition of the population of the oases are reflected.

The research of A. Kayumov, the author of articles on the ethnic composition and location of the population of the southern regions of Uzbekistan (especially the Surkhandarya oasis), revealing ethnic processes, is also noteworthy. In an article on the ethnic composition of the Sherabad oasis in the XIX - early XX centuries, A. Kayumov provides information about the location of ethnic groups living in the oasis - Chigatoys, bells, blacksmiths and others.

In the article co-authored by A. Kayumov and A. Ashirov, the ethnic characteristics of the population Uzbeks living in Surkhandarya's Sariosiyo, Avlod, Bibishirin, Rabot, Kofrun, Shayit, Gaza, Poygaboshi - Turks, Kungrad, Chigatay and Tajiks living in Darband, Sayrob, Machay, Boysun villages are described [13].

In studying the ethnic history and ethnic composition of the population of the southern oases, it is worth noting the work of N.N. Tursunov, who studied the ethnic characteristics of the Surkhan oasis [14]. The researcher studied the ethnic composition of the South Surkhandarya oasis and tried to shed light on this issue based on the data of B.Kh. Karmisheva and the materials of the 1926 zoning commission. It should be noted that the author has enriched the materials of B. Kh. Karmisheva about the ethnoses in the oasis with new information.

In the multi-volume book "Uzbeks" in the section "Narody i kultury" the authors dwell on the ethnic history of the Uzbek people, as well as information on the ethnic history of the population living in the south of Uzbekistan [15].

R.A. Rajabov's monograph "History and ethnography of the Arabs in Uzbekistan" is a historical and ethnographic study of the Arabs who have lived in the southern regions of Uzbekistan for centuries. It describes the settlement of the Arabs in Central Asia as a result of the invasions of the Arab historical state and in the following centuries in the lands of Movarounnahr. The issues of participation of Arabs in the socio-economic and ethnocultural processes in our country in different historical periods are also described. There is also valuable information about the ethnic history and location of Arabs and other ethnic groups living in the region, based on sources and scientific research created by historians, ethnographers and linguists [16].

Researcher M. Usmanov's work on the ethnic history of Uzbek bells living in the southern oases is also noteworthy [17]. We have already mentioned his work with ethnologist $\mathrm{O}$. Buriev, so the researcher's special monograph on the ethnic history of 


\section{Coverage of Problems in the Ethnic History of the Population of Kashkadarya and Surkhandarya Oases in the Scientific Researches during the Years of Independence}

the Uzbek bells explains the ethnic history and genealogy of the Uzbek bells, which make up the majority of the population of the southern regions. Information on the history of the bell seed is also given in the books of researchers K. Berdikulov, T. Batyrov [18]. Researchers who want to study the ethnic history of the bells and their location across the southern regions can, of course, obtain relevant information for themselves from these studies.

F. Ochildiev's monograph, which explains the socio-political and economic changes in the principalities of the Surkhandarya oasis in the second half of the XIX - early XX centuries, also addresses the issue of settlement and ethnic composition of the oasis principalities [19].

Historians O. Jurakulov [20], P. Ravshanov [21], local historian B. Pulatova [22] also provide information on the ethnic history and location of the population of the region.

O. Jurakulov's book dedicated to the Turkmen of Chandir village of Kashkadarya tells about the ethnic history of Chandir Turkmens, their interaction with Samarkand, Bukhara, Khorezm regions and Chandir tribes living in Chorjoi and Dashovuz regions of Turkmenistan. Scholars have tried to prove that the ethnogenesis of the Chandir Turkmen dates back to the ancient Turkic tribe Oguz, based on the works of medieval scholars Mahmud Kashgari (XI), Rashid-id-Din (XIII - XIV centuries), Abulgazi Bahodirkhan (XVII) and Soviet and Turkmen scholars.

O. Jurakulov's monograph "Kashkadarya mangitlari" is dedicated to the history of mangits, one of the Uzbek tribes that made up the majority of the population of the Bukhara khanate. The book provides information about the ethnic history, number and location of the Mangits living in the village of Mangit in Kashkadarya region.

In her work, B. Pulatova tried to cover the history of the village of Denov, located in Kasbi district of Kashkadarya region. The author also refers to the ethnic history of the inhabitants of the village of Denau. Based on the words of the villagers, he records the names of more than a hundred tribes who live there. Especially noteworthy is the list of the genealogy of the Denau Sayyids.

\section{CONCLUSIONS}

In conclusion, it can be said that from the first years of independence of Uzbekistan, significant research has been conducted to study the problems of ethnogenesis and ethnic history of the Uzbek people. In the course of studying this problem, our researchers have gained some insights into the participation of ethnic groups living in the south in ethnic processes due to the increase in the amount of information on the ethnic history, ethnic composition, formation and location of the population in the southern regions of Uzbekistan. Research on the ethnic history of the oasis population is still ongoing.

\section{REFERENCES}

1) Shaniyazov K. On the issue of Turkic-lingual components in the composition of the Uzbek people // PEEINSAK. M., 1991; the same author. Karluk state and Karluks. T.: Sharq, 1999. -192 p.; the same author. The process of formation of the Uzbek people. T.: Sharq, 2001. -464 p.

2) Askarov A. Ahmedov B. Origins of the Uzbek people (initial comments) - "Voice of Uzbekistan", January 20, 1994; Askarov A.A. Some theoretical and scientific methodological bases of ethnogenesis and ethnic history of the Uzbek people // History of Uzbekistan, 2002. №4. Pages 54-60; the same author. Ethnogenesis and ethnic history of the Uzbek people. T., 2007

3) Ahmedov B.A. Uzbek nation. T.: Meros, 1992; the same author. Lessons from history. - T.: Teacher, 1994. $432 \mathrm{p}$.

4) Jabborov I. Ethnography of the Uzbek people. T., 1994. 320 b; the same author. Uzbeks: lifestyle and culture. (Ethnohistorical plates). - T., 2003. 208 b; the same author. Fundamentals of World Ethnology. - T.: Yangi asr avlodi, 2005. 316 p; the same author. Uzbeki. T., 2007.

5) Shoniyozov K. Some issues of the process of formation of the Uzbek people // Social sciences in Uzbekistan. 1996, №6. Pages 79-87; the same author. Some theoretical issues of the Uzbek people // Social sciences in Uzbekistan. 1998. №6, pp. 31-44.

6) Shoniyozov K. The process of formation of the Uzbek people. - T.: Sharq, 2001. P. 462.

7) Askarov A.A. Some aspects of the study of ethnogenesis and ethnic history of the Uzbek people // Materials to the ethnic history of the Middle Asia. T.: Fan, 1986. -B. 3-14; the same author. Some theoretical and scientific methodological bases of ethnogenesis and ethnic history of the Uzbek people // History of Uzbekistan, 2002. Issue 4. Pages 54-60; the same author. Ethnogenesis and ethnic history of the Uzbek people. T., 2007. 


\section{Coverage of Problems in the Ethnic History of the Population of Kashkadarya and Surkhandarya Oases in the Scientific Researches during the Years of Independence}

8) Shoniyozov K. The process of formation of the Uzbek people. - T.: Sharq, 2001. -P. 30; Doniyorov A. Ethnographic research in Uzbekistan in the XX century: the main stages, problems, prospects of development. -P.146; Ashirov A.A. Ethnology of Uzbekistan in the years of independence: achievements, problems and their solutions. -P. 28.

9) Askarov A. History of the origin of the Uzbek people. - Tashkent.: “Uzbekistan", 2015. 672 p.

10) Ahmedov B.A. Sources of history of the peoples of Uzbekistan. T.: Teacher, 1991. 216 pages; Uzbek nation. T.: Meros, 1992; the same author. Lessons from history. - T.: Teacher, 1994. 432 p.; Askarov A. Ahmedov B. Origins of the Uzbek people (initial comments) - "Voice of Uzbekistan", January 20, 1994; Ahmedov B. Sources of history of Uzbekistan. T., 2001.

11) Jabborov I. Ethnography of the Uzbek people. T., 1994. 320 p.; The same author. Uzbeks: lifestyle and culture. (Ethnohistorical plates). - T., 2003. 208 p.; the same author. Fundamentals of World Ethnology. - T.: Yangi asr avlordi, 2005. 316 p; the same author. Uzbeki. T., 2007.

12) Buriyev O. Usmonov M. Uzbeks: ethnic history and ethnocultural processes. Samarkand, 2008. 244 p.

13) Qayumov A.R. The composition of the population of the Sherabad oasis (XIX century - early XX century) // Social Sciences in Uzbekistan, 1998. №3. -P. 34-38; the same author. Some factors of ethnic processes in the Surkhan-Sherabad valley in the late XIX-early XX centuries // History of Uzbekistan. 2001. №4; the same author. Uzbek tribes and clans // Ethnic atlas of Uzbekistan. Elina, 2002; the same author. The ethnos of "repression" in the ethnocultural environment of Uzbekistan. (Some materials on the ethnic history of the Uzbek people). Ethnology of Uzbekistan: new views and approaches. Proceedings of the international scientific conference dedicated to the 80th anniversary of Academician of the Russian Academy of Sciences K.Shoniyazov. T.: 2004.115 - 119 p.; Kayumov A.R., Ashirov A.A. Features of the ethnic composition of Baysuna // Trudy Baysunskoy nauchnoy ekspeditsii. - T., 2003. Vyp. 1; Tursunov N.N. The family is a reliable support of society // Harmonious human education. - Termiz, 2000. -P. 63-65; the same author. Do you know the people of Surkhandarya? // Communication. -2002. -№ 4. -P. 47-48; the same author. Identity reflected in clothes // Tafakkur. 2003. -№. -P. 120-121; the same author. Bread and tableware // Communication. -2003. -№ 4. -P. 47-48; The same author. The end of the XIX - beginning of the XX century Termez Economic and Biocentric Center // Materials of the Republican scientific conference "Actual problems of history and archeology of Uzbekistan". -Samarkand, 2003. -P. 119122; Tursunov S., Tursunov N. The end of the XIX century - the beginning of the XX century. -2003. № 4. -P. 70-74; Those authors. National costumes of the population of the Southern Surkhandarya oasis in the late XIX - early XX centuries // Social sciences in Uzbekistan. -2003. № 4. -P. 57-60; Tursunov N.N. Guarantee of life literature // Echo from Maziy. -2006. -№ 3. -P. 32-35; Tursunov S., Tursunov N., Pardaev T., Qurbonov A. History and culture of Uzbekistan - Surkhandarya ethnography. - T.: Alisher Navoi National Library of Uzbekistan Publishing House, 2006. -278 p.

14) Arifxanova Z.X. (ed.), Abashin S.N., Alimova D.A. Uzbeki // Narody i kultury. - M .: Nauka, 2011. -P. 64-72.

15) Rajabov R. History and ethnography of the Arabs in Uzbekistan: the middle of the XIX century - the beginning of the XXI century. T .: Sharq, 2012. $-416 p$

16) Usmonov M. Uzbek-bells of Southern Uzbekistan and Khorezm oasis: issues of interaction and influence // Proceedings of the IV Republican scientific-theoretical conference on current issues of ethnology of Uzbekistan. T. - N., 2007. P. 87 91; The same author. Utov-South Uzbekistan as the main settlement of bells // Science, development and youth. Proceedings of the scientific-practical conference. - Against, -2008. -P. 169-172; The same author. From the ethnic history of Uzbek bells // Proceedings of the scientific-practical conference "The role of Nasaf scholars in world culture." - Against, -2008. -P. 232-236; Buriyev O., Usmonov M. Uzbeks: ethnic history and ethnocultural processes. Samarkand, 2008. 244 p. et al.)

17) Berdikulov Q. Calls. T.: Writer, 1999; Botirov T. - T., 2006. 72 p.

18) Ochildiev F. Socio-biological and economic changes in the principalities of the Surkhandarya oasis. T., 2008. -P. 29-51.

19) Jo'raqulov O. Chandir Turkmens. T.: Fan, 1992. -235 p.; The same author. Kashkadarya mangits. T.: Fan, 1993. - P. 255.

20) Ravshanov P. History of Kashkadarya. T.: Fan, 1995. 784 p.; The same author. History of injection. - T.: Yangi asr avlodi, 2006; Saidov M., Ravshanov P. History of Jeynov. - T.: Ibn Sino, 1996; Ravshanov P., Uzokov R. The value of our ancestors. - T.: Sharq, 1999. -384 p.

21) Pulatova B. The Denau people are in the mirror of history. - T.: Fan, 1994. 144 p. 